\title{
ГЕОСТАТИЧЕСКИЙ АНАЛИЗ АТРИБУТОВ СЕЙСМИЧЕСКОЙ ЗАПИСИ С ЭЛЕМЕНТАМИ НЕЙРОСЕТЕВОГО МОДЕЛИРОВАНИЯ В УСЛОВИЯХ АРТИНСКИХ БИОГЕРМОВ ПЕРМСКОГО КРАЯ
}

Ярлыков М.Ю., Каиик М.А.

(ОАО «Центральная Геофизическая Экспедичия》, Москва, Россия)

В данной работе рассмотрена методика геостатического анализа атрибутов сейсмической записи с элементамн нейросетевого моделирования в условиях артинских биогермнњг массивов на примере участка работ в Пермской области. С использованием многочисленного перебора комбинаций атрибутов, для достижения устойчивого результата проведена кластеризация исследуемой территории по артинскому продуктивному пласту.

В настоящее время одной из актуатьнейпих задач комплексной интерпретации сейсмических и скважинных данных является построение карт основных подсчетных параметров: эффективных толщин и пористости.

Для прогноза коллекторов в межскважинном пространстве, построения принципиальньг, а таке трехмерных цифровых моделей продуктивных пластов использовалась методика геостатистического анализа сейсмических атрибутов. Для этих целей на первом этапе были получены кубы различных параметров сейсмической записи. (Рис. 1)

Предварительный анализ корреляционных связей сейсмических атрибутов и подсчетных параметров КІ (коэффициент пористости) параметра Нэф (эффективная мощность коллектора) проводился в интерактивном режиме с использованием процесса седиментационного анализа как исходного сейсмического, так и рассчитанных кубов различных сейсмических атрибутов. Использование этой методики позволяет проводить экспресс-анализ корреляционных связей сейсмических атрибутов и параметров Кп и Нэф, определенных в точках скважин, на этапе расчета карт этих сейсмических атрибутов. Затем набор карт по каждому из пластов в различных вариациях были поданы на вход программы нейронных сетей. Использовались нейронные сети обобщенной регрессии (GRNN). В результате работы данной программы на выходе были получены карты прогнозного параметра Нэф и график результируюшей статистической зависимости комплексного прогнозного атрибута с параметром Нэф, определенным по скважинам.

Кластерный анализ выполнен без привлечения скважинных данных по эффективным параметрам и использован для выделения по совокупности атрибутов сейсмхческой записи схожих областей. То есть решается задача мтогомерной классификации данпых по сейсмическим признакам - выделяются сейсмические фащии. В комплексе с прогнозными картами эффективной мощности коллекторов эти карты должны отображать в первом приблюжения сейсмофациальную обстановку. (Рис. 2)

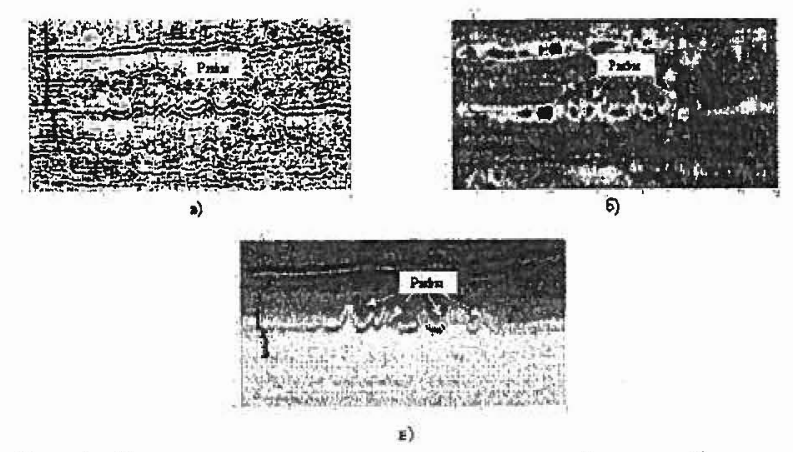

Рис. 1. Вертикальное сечение различных кубов атрнбутов: а) униполярные фазы; б) мтновенные амплитуды; в) акустический импеданс

\section{Кластеризации плошади для артинского пласта}

\section{Ipor возная карта $\mathrm{H} э \phi$}
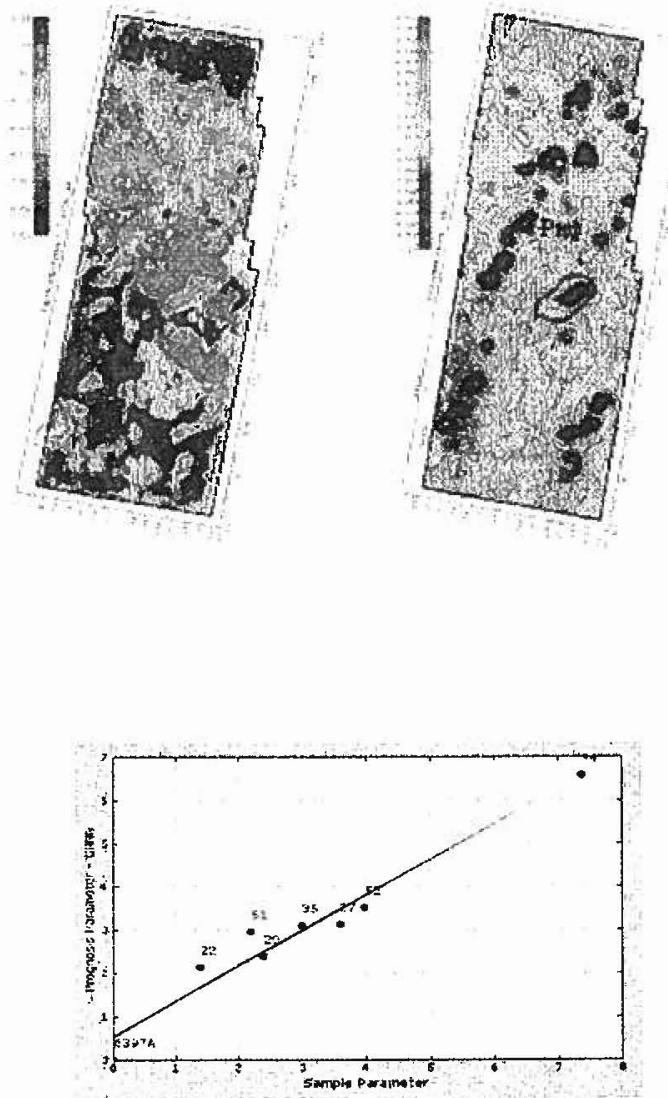

Регрессионная зависимость прогнозного параметра по сейсмическкм атрибутам от Нэф по скважинным данным

Рис. 2. Результат кластеризация и прогнозный параметр Нзф артинских отложений 